\title{
Pengaruh Motivasi Kerja, Kemampuan dan Kreativitas Terhadap Kinerja UKM Kerupuk Udang di Kecamatan Tungkal Ilir Kabupaten Tanjung Jabung Barat
}

\author{
Indra Jaya, Sumarni \\ Fakultas Ekonomi dan Bisnis, Universitas Jambi, Indonesia
}

\begin{abstract}
ABSTRAK
Penelitian ini berjudul pengaruh Motivasi Kerja, Kemampuan dan Kreativitas terhdap kinerja UKM ( studi kasus usaha pengolahan kerupuk udang) di Kecamatan Tungkal Ilir kabupaten tanjung jabung Barat. Tujuan dilakukannya penelitian ini adalah untuk : (1) Menganalisis pengaruh motivasi kerja terhadap kinerja usaha UKM pengolahan kerupuk udang di Kecamatan Tungkal Ilir Kabupaten tanjung jabung Barat. (2) (1) Menganalisis pengaruh kemampuan terhadap kinerja usaha UKM pengolahan kerupuk udang di Kecamatan Tungkal Ilir Kabupaten tanjung jabung Barat (3) (1) Menganalisis pengaruh kreativitaskerja terhadap kinerja usaha UKM pengolahan kerupuk udang di Kecamatan Tungkal Ilir Kabupaten tanjung jabung Barat (4) (1) Menganalisis pengaruh motivasi kerja, kemaaampuan dan kreativitas terhadap kinerja usaha UKM pengolahan kerupuk udang di Kecamatan Tungkal Ilir Kabupaten tanjung jabung Barat. Temuan penelitian ini menunjukkan bahwa, motivasi kerja, kemampuan dan kreativitas, baik msecara parsial maupun sevcara simultan berpengaruh positif dan signifikan terhadap kinerja UKM pengolahan kerupuk udang di Kecamatan Tungkal Ilir Kabupaten tanjung jabung Barat. Dan hal ini memberikan implikasi teoritik penting bagi pengembangan teori-teori motivasi kerja, kemampuan dan kreativitas terhadap kinerja usaha UKM. Pesan menegerial penting dari temuan penelitian ini adalah bahwa kinerja usasha UKM khususnya pengussaha kerupuk udang akan dapat ditingkatkan melalui motivasi kerja yang tinggi, diikuti oleh kemampaun kerja serta kreativitas dari pengusaha itu sendiri.
\end{abstract}

Kata Kunci: Motivasi kerja, kemampuan, kreativitas, UKM, pengusaha kerupuk udang.kuala tungkal. Tanjung jabung barat.

\section{PENDAHULUAN}

Usaha mikro kecil dan menengah merupakan salah satu bentuk organisasi profit atau bisnis. Dalam pengelolaan sebuah organisasi yang berorientasi bisnis atau profit semua aspek manajemen dan organisasi harus menjadi perhatian, tidak terkecuali aspek sumberdaya manusia dan perilakunya dalam organisasi tersebut. Aspek sumberdaya manusia ini menjadi penting karena salah satu faktor penentu keberhasilan kinerja suatu organisasi bisnis adalah pengelolaan SDM dan perilaku manusianya yang akan menjalankan berbagai aspek manajemen lainnya. Hasil penelitian Cassel, et al (2002) terhadap perusahaan UMKM menunjukan bahwa praktek pengelolaan manajemen SDM menentukan kesuksesan perusahaan tersebut dalam mencapai tujuannya. Kuncoro (2000) mengungkapkan ada beberapa kendala yang dialami oleh UMKM dalam menjalankan usahanya. Kendala tersebut berupa tingkat kemampuan, ketrampilan, keahlian, manajemen sumber daya manusia, kewirausahaan, pemasaran dan keuangan. Lemahnya kemampuan manajerial dan sumberdaya manusia ini mengakibatkan pengusaha kecil tidak mampu menjalankan usahanya dengan baik.

Keragaman yang dimiliki Kecamatan Tungkal Ilir menjadikan daya tarik untuk pendatang, keadaan ini dapat mendukung kesuburan pertumbuhan UKM.Banyaknya pendatang yang berkunjung di Kecamatan Tungkal Ilir khususnya Kuala Tungkal menciptakan iklim usaha yang baik bagi UKM sehingga dapat menyerap tenaga kerja dan meningkatkan kesejahteraan masyarakat.Bahkan dengan pemerintah menjadikan sentra industri UKM sebagai daerah tujuan pendatang / wisata.

Kabupaten Tanjung Jabung Barat adalah salah satu Kabupaten yang terletak di Pantai Timur Provinsi Jambi dengan luas $5.009,82 \mathrm{Km}^{2}$ atau sekitar $\pm 9.38 \%$ dari total luas wilayah Provinsi jambi yang mencapai 53.435,72 $\mathrm{Km}^{2}$. sampai saat ini, Kabupaten Tanjung jabung Barat terdiri dari 13 kecamatan dengan 70 desa/kelurahan. Dilihat dari jumlah penduduk dan kepadatan 
penduduknya, Kecamatan Tungkal Ilir dengan Ibukotanya Tungkal IV Kota merupakan Kecamatan yang memiliki jumlah penduduk terbanyak yaitu 67.817 orang dari 278.741 orang dengan tingkat penyebarannya mencapai $24.33 \%$. Disamping itu, dari sisi kepadatan penduduknya, Kecamatan Tungkal Ilir juga memiliki tingkat kepadatan paling tinggi diantara 12 Kecamatan lainnya yang ada di kabupaten Tanjung Jabung Barat dengan tingkat kepadaatan penduduknya mencapai 676 orang per $\mathrm{Km}^{2}$. Dimana penduduknya selain bertani, banyak juga yang memilih berwirausaha dengan berbagai macam jenis usaha pada sektor informal, khususnya industry rumahtangga. .

Tingginya pertumbuhan industri rumahtangga di Kecamatan Tungkal Ilir menumbuhkan daya saing antar mereka untuk bertahan dalam bisnisnya.Salah satu daerah potensil untuk usaha industry rumahtangga adalah kelurahan Tungkal Harapan, Tungkal IV Kota, Tungkal III dan Tungkal II. Di daerah ini, sentra indusri kecil dan industri rumahtangga menjadi andalan karena tidak hanya berhasil merambah pasar domestik melainkan juga pasar internasional.Terdapat industri rumahtangga yang pertumbuhannya sangat pesat, yakni industry rumahtangga yang berbasis industri pengolahan kerupuk udang yang dapat menembus pasar luar negeri khsusnya malaysia.

Berkembangnya industri kerupuk udang di wilayah Kecamatan Tungkal Ilir pada dasarnya cukup beralasan mengingat mayoritas masyarakatnya banyak yang hidup sebagai petani dan nelayan yang kesehariannya menangkap ikan di laut maupun dengan menggunakan keramba. Salah satu hasil tangkapan yang banyak dihasilkan oleh para nelayan adalah udang. Mengingat udang adalah bahan makanan yang tidak tahan lama (cepat busuk) sehingga diperlukan penanganan untuk memperlama masa penggunaannya. Beberapa cara dapat dilakukan antara lain pembuatan terasi udang, pembuatan udang kering dan kerupuk udang. Pembuatan kerupuk udang selain menambah lamanya penggunaan udang juga merupakan salah satu cara untuk menambah variasi dari penggunaan udang, dimana udang adalah merupakan hewan yang mengandung protein yang sangat tinggi yang sangat dibutuhkan manusia. Dengan adanya kerupuk udang ini maka bagi orang yang tidak menyukai konsumsi udang seraca langsung dapat pula menikmati udang dengan adanya kerupuk udang. Kerupuk udang merupakan bahan makanan dengan bahan baku udang dan tepung sagu yang telah diawetkan dengan cara dijemur sehingga penggunaannya untuk jangka waktu yang lama, jika dijemur lagi setelah beberapa waktu maka akan memperlama masa penggunaannya..

Teknologi yang dipergunakan dalam pembuatan kerupuk udang ini masih mempergunakan teknologi yang sederhana terutama dalam proses pencampuran bahan-bahan dan pengolahan bahan hanya dengan mempergunakan tenaga manusia. Teknologi yang dipergunakan adalah pada proses penghancuran udang yaitu dengan menggunakan mesin penghancur udang, dan proses mencampur udang dengan bumbu-bumbu mempergunakan mixer khusus. Dalam proses pengeringan juga masih mengandalkan kekuatan sinar matahari, belum mempergunakan mesin pengering.

Mengingat sumber bahan baku kerupuk udang ini mudah didapat di wilayah kecamatan tungkal ilir, maka persaingan usaha pengolahan kerupuk yang berbahan dasar udang ini sangat tinggi. sehingga menuntut para pelaku dalam bidang industri pengolahan kerupuk udang untuk dapat selalu menggunakan strategi bersaing yang relevan dengan perkembangan kondisi lingkungan bisnisnya agar dapat mempertahankan keunggulan bersaing yang berkesinambungan terhadap perusahaan sejenis serta tetap eksis dalam lingkungan bisnisnya.

Salah satu faktor yang menjadi pengaruh bagi peningkatan kinerja maupun pertumbuhan usaha industri rumahtangga yaitu daya saing yang ditentukan oleh kemampuan SDM, termasuk diantaranya adalah kreativitas dan motivasi kerja para pengusha yang bekerja pada sektor ini untuk memproduksi kerupuk udang dengan kualitas barang yang baik, harga bersaing serta desain yang menarik. 
Robbins (2008) mendefenisikan motivasi kerja sebagai kemauan untuk mengupayakan level-level usaha kerja yang tinggi menuju tujuan-tujuan keorganisasian, dikondisikan oleh kemampuan usaha kerja untuk memenuhi beberapa kebutuhan individual. Kebutuhan menurut defenisi ini adalah sebuah keadaan internal yang membuat akibat-akibat atau hasil-hasil tertentu kelihatan menarik. Suatu kebutuhan yang tidak terpenuhi atau tidak terpuaskan akan menciptakan tensi yang mendorong gerakan didalam diri individu. Gerakan ini kemudian menimbulkan sebuah prilaku berusaha untuk menentukan tujuan-tujuan tertentu yang jika tercapai akan memuaskan kebutuhan tersebut dan menjurus pada pengurangan tensi.

Berdasarkan konsep yang dikembangkan oleh Mc clelland, bahwa motivasi kerja dapat dilihat dari 3 dimensi, diantaranya adalah (a) Need for Achievement, yaitu dorongan akan tanggung jawab, berani mengambil resiko dan berprestasi lebih tinggi. (b) Need for Affiliation, yaitu dorongan yang ada dalam diri seseorang untuk berintereaksi sosial, kerjasama, pengakuan kemampuan dan sportivitas (c) Need For Power, yaitu dorongan yang muncul dalam diri seseorang yang berkaitan dengan hala-hal seperi siap untuk melakukan pekerjaan yang menantang, ingin mempunyai kebebasan dalam bekerja. Dengan melakukan survey terhadap ketiga dimensi tersebut yang ditujukan pada 10 orang pengusaha dari 40 pengusaha kerupuk udang yang ada di wilayah Kecamatan Tungkal Ilir, memperlihatkan bahwa sekitar 69\% diantaranya merespon positif terhadap ketiga dimensi tersebut. Artinya, motivasi kerja mereka yang didorong oleh ketiga dimensi tersebut termasuk tinggi.

Demikian juga halnya dengan kemamampuan kerja, maka survey awal dilakukan terhadap 10 orang pengusaha kerupuk udang di wilayah kecamatan Tungkal Iilir, dimana dimensi kemampuan yang dikembangkan dalam 3 dimensi yaitu (a) pengetahuan (b) keterampilan dan (c) sikap mental. Hasil survey juga menunjukkan bahwa $60 \%$ menilai setuju terhadap pernyataan yang diajukan, Artinya, dari ketiga aspek tersebut, kemampuan mereka masih dinilai tinggi.

Dalam kaitannya dengan kreativitas, Suryana (2008) menyatakan bahwa kreativitas adalah: "Berpikir sesuatu yang baru". "Kreativitas sebagai kemampuan untuk mengembangkan ide-ide baru dan untuk menemukan cara-cara baru dalam memecahkan persoalan dalam menghadapi peluang. Kreativitas ini untuk kemudian dikembangkan dalam 3 dimensi diantaranya kebaharuan, kebergunaan dan dapat dimengerti ( Suyana, 2008). Dengan menggunakan ketiga dimensi ini, survey yang dilakukan melalui instrument kuesioner yang ditujukan pada 10 orang pengusaha kerupuk udang di Kecamatan Tungkal Ilir Kabupaten Tanjung Jabung Barat memperlihatkan bahwa Sekitar 70\% responden merespon setuju terhadap pernyataan yang diajukan dan hanya $30 \%$ saja yang kurang setuju. Artinya, dari sisi kreativitas ini juga memperlihatkan bahwa para pengusaha kerupuk udang di wilayah Kecamatan Tungkal Ilir memilikimkreativitas yang baik.

Karena industri pengolahan kerupuk udang ini merupakan salah satu Industri rumahtanggga yang memiliki peran yang sangat penting bagi pertumbuhan ekonomi di Kecamatan Tungkal Ilir Kabupaten Tanjung Jabung Barat diikuti pula oleh tingginya motivasi pengusaha, kemampuan pengusaha dan kreativitas pengusaha kerupuk udang di wilayah Kecamatan Tungkal Ilir, maka dalam penelitian ini peneliti mencoba melihat apakah ada pengaruh ketiga variable tersebut bagi peningkatan kinerja usaha industri pengolahan kerupuk udang di Kecamatan Tungkal Ilir kabupaten Tanjung jabung Barat. Un tuk itulah, maka ketertarikan peneliti ini dituangkan dalam suatu bentuk penelitian dengan judul " "Pengaruh Motivasi kerja, kemampuan dan kreativitas terhadap kinerja Usaha Kecil dan Menengah (studi kasus usaha pengolahan kerupuk udang di kecamatan tungkal ilir kabupaten tanjung jabung barat" 


\section{METODE PENELITIAN}

\subsection{Jenis Dan Desain Penelitian}

Penelitian ini termasuk penelitian kausalitas, bertujuan untuk menguji hipotesis mengenai hubungan kausalitas satu variabel dengan variabel lainnya. Model penelitian ini diharapkan dapat menjelaskan hubungan sebab akibat antar variabel dalam penelitian, sekaligus menghasilkan kesimpulan yang dapat dipergunakan untuk mengembangkan ilmu pengetahuan, khususnya kewirausahaan.

\subsection{Populasi dan Sampel}

Populasi dalam penelitian ini adalah seluruh usaha kecil dan rumahtangga yang berada di Kecamatan Tungkal Ilir Kabupaten Tanjung Jabung. Berdasarkan data dari Dinas Koperasi, UMKM dan Perdagangan Kecamatan Tungkal Ilir Kabupaten Tanjung Jabung ada 369 unit usaha usaha kecil. Dari 369 usaha kecil dan rumahtangga yang ada 40 diantaranya adalah mereka yang berusaha dalam bidang pengolahan kerupuk udang yang tersebar di beberapa desa / kelurahan di wilayah. Kecamatan Tungkal Ilir. Diantaranya adalah Desa/ kelurahan Tungkal Harapan dengan 15 usaha, Desa / kelurahan Tungkal IV Kota 10 usaha, Desa / kelurahan Tungkal III 6 usaha, Tungkal II 5 usaha dan tungkal I ada 4 usaha. Untuk kepentingan pengambilan sampel, mengingat jumlah pengusaha kerupuk udang jumlahnya terbatas, maka dalam penelitian ini tehnik pengambilan sampel yang dilakukan adalah dengan mengambil semua pengusaha kerupuk udang yang ada (Exhaustive sampling)

\subsection{Operasional Variabel}

Tabel 1 . Operasionalisasi Variabel

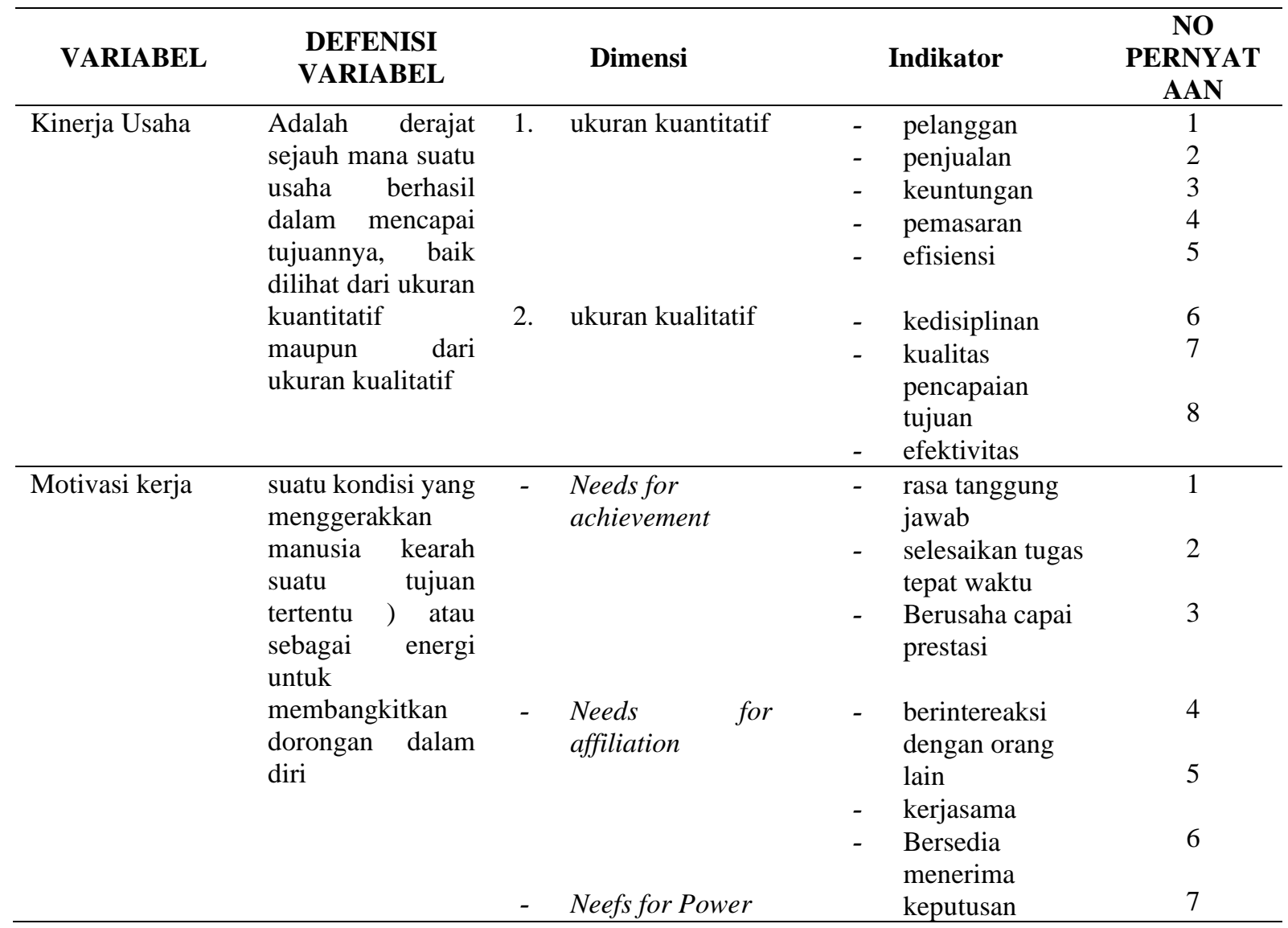




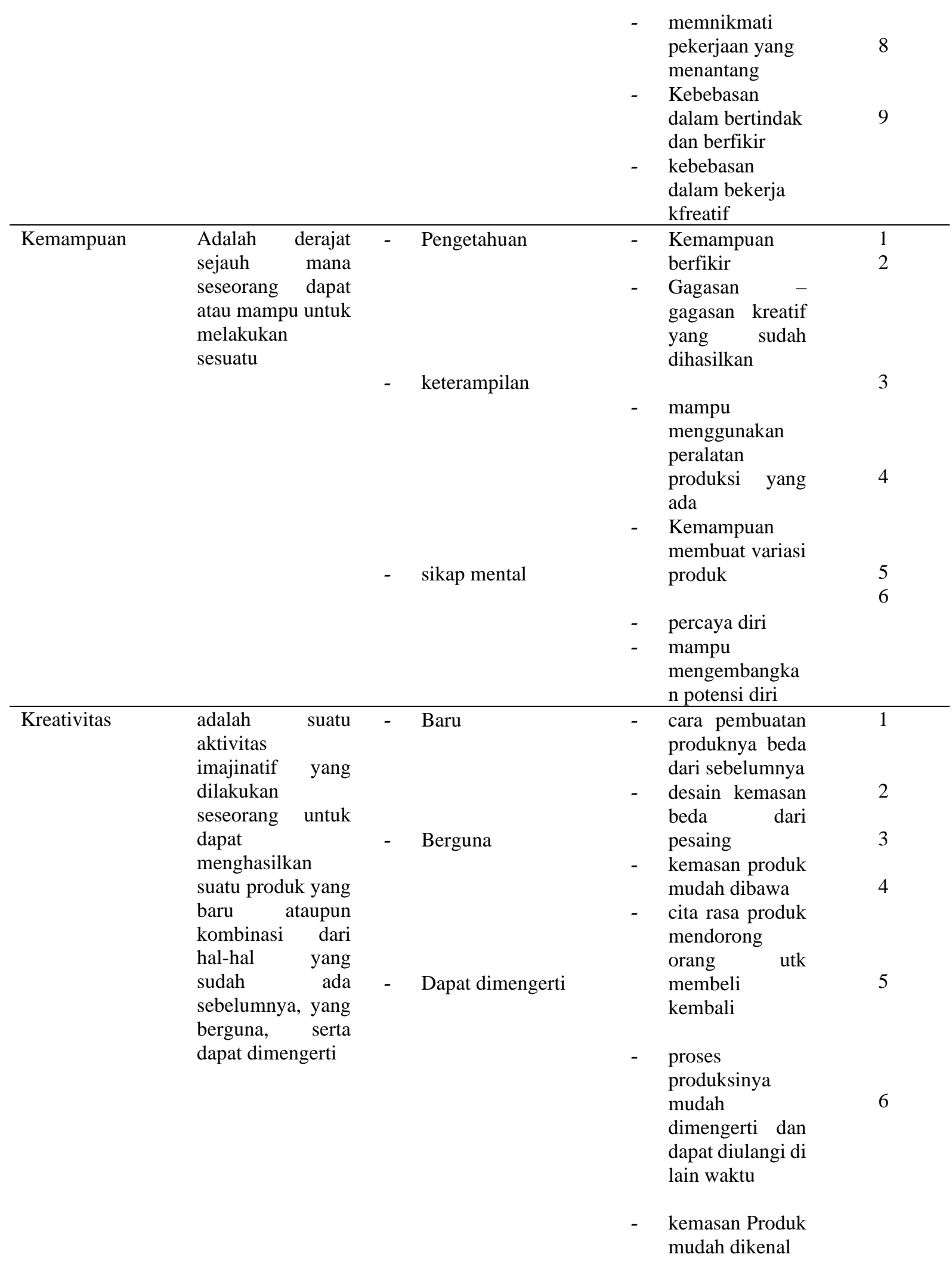




\subsection{Metode Pengumpulan Data}

Pengumpulan data yang digunakan dalam penelitian ini adalah menggunakan kuesioner secara personal. Metode ini memberikan tanggapan atas pernyataan kuesioner. Dalam penelitian ini kuesioner dibagikan langsung pada responden dan peneliti dapat memberikan penjelasan mengenai tujuan survey dan pertanyaan yang kurang dipahami oleh responden serta tanggapan atas kuesioner dapat langsung dikumpulkan oleh peneliti setelah diisi oleh responden. Kuesioner secara personal digunakan untuk mendapatkan data tentang dimensi-dimensi dari kontrukkontruk yang sedang dikembangkan dalam penelitian ini.

\subsection{Tehnik Analisis Data Dan Uji Hipotesis}

analisa deskriptif digunakan untuk menggambarkan karakteristik responden dan variabel penelitian tanpa melakukan pengujian. Caranya adalah dengan menyusun tabel distribusi frekwensi untuk melihat masuk dalam kategori manakah variabel yang sedang diteliti. Untuk sampai pada kriteria tersebut, maka dibuat kriteria pengklasifikasian yang mengacu pada ketentuan yang dikemukakan oleh Husein (2008), dimana rentang skor dan rentang skala ditentukan dengan rumus sebagai berikut :

\section{Penentuan Rentang Skala}

$$
\begin{aligned}
&(\mathrm{m}-1) \\
& \text { Dimana }: \mathrm{RS}=\text { Rentang Skala } \\
& \mathrm{n}=\text { Jumlah sampel } \\
& \mathrm{m}=\text { Jumlah alternative jawaban item }
\end{aligned}
$$

Sehingga :

$$
\begin{aligned}
\text { RS } & =\frac{40(5-1)}{-------} \\
& =32
\end{aligned}
$$

\subsection{Penentuan Rentang Skor}

$\begin{array}{ll}\text { Rentang Skor terendah } & =\mathrm{n} \times \text { skor terendah } \\ & =40 \times 1 \\ & =40 \\ \text { Rentang skor tertinggi } & =\mathrm{n} \times \text { skor tertinggi } \\ & =40 \times 5 \\ & =200\end{array}$

Karena skala yang digunakan dalam penelitian ini adalah skala likert $1-5$, maka kategori pengklasifikasian untuk variabel motivasi kerja, kemampuan, kreativitas dan kinerja dapat pada tabel dibawah ini : 
Tabel 4.3. Rentang pengklasifikasian variabel

\begin{tabular}{ccc}
\hline Variabel & Rentang penilaian & Klasifikasi \\
\hline \multirow{2}{*}{ Kinerja } & $40-72$ & Sangat rendah \\
& $73-105$ & Rendah \\
& $106-138$ & Biasa saja \\
& $139-171$ & Tinggi \\
& $172-204$ & Sangat Tinggi \\
\hline Motivasi & $40-72$ & Sangat rendah \\
Kerja & $73-105$ & Rendah \\
& $106-138$ & Biasa saja \\
& $139-171$ & Tinggi \\
& $172-204$ & Sangat Tinggi \\
\hline Kemampuan & $40-72$ & \\
& $73-105$ & Sangat rendah \\
& $106-138$ & Rendah \\
& $139-171$ & Biasa saja \\
& $172-204$ & Tinggi \\
& & Sangat Tinggi \\
\hline & $40-72$ & \\
& $73-105$ & Sangat rendah \\
& $106-138$ & Rendah \\
& $139-171$ & Biasa saja \\
& $172-204$ & Tinggi \\
& & Sangat Tinggi \\
\hline
\end{tabular}

Dalam analisis deskriptif ini, penulis juga menggunakan beberapa tehnik untuk mendeskripsikan data hasil penelitian yaitu dengan menggunakan tehnik penghitungan Mean, Modus dan standar deviasi. Dalam analisis deskriptif ini peneliti menggunakan perangkat lunak (software SPSS)

\subsection{Analisis Verifikatif}

Analisis ini digunakan untuk menguji hipotesis penelitian yang telah dirumuskan sebelumnya, yaitu untuk mengetahui apakah ada pengaruh antara variabel motivasi kerja, kemampuan dan kreativitas dengan kinerja Usaha Pengolahan kerupuk udang di wilayah Kecamatan Tungkal Ilir Kabupaten tanjung jabung Barat. Dalam hal ini, tehnik statistik yang digunakan adalah tehnik Regresi Linier Berganda. Adapun persamaan regresi yang digunakan adalah sebagai berikut (Sugiyono, 2006 )

$Y=\beta_{0}+\beta_{1} X_{1}+\beta_{2} X_{2}+\beta_{3} X_{3}+e$

$\begin{array}{lll}\text { Dimana : } & \mathrm{Y} & =\text { Kinerja } \\ & \mathrm{X}_{1} & =\text { Motivasi kerja } \\ \mathrm{X}_{2} & =\text { kemampuan } \\ \mathrm{X}_{3} & =\text { kreativitas } \\ \beta_{0} & =\text { intercept } \\ \beta_{1}, \beta_{2}, \beta_{2} & =\text { parameter yang ditaksir (koeifisien regresi) } \\ \mathrm{e} & =\text { Faktor kesalahan }\end{array}$




\section{HASIL DAN PEMBAHASAN}

\subsection{Hasil Penelitian}

Untuk melihat bagaimana gambaran kinerja usaha pengelolaan kerupuk udang di Kecamatan Tungkal Ilir kabupaten tanjung jabung Barat kedalam beberapa dimensinya, diantaranya adalah (a) ukuran kuantitatf (b) ukuran kualitatif yang dikumpulkan terhadap 40 orang pengusaha pengolahan kerupuk udang di Kecamatan Tungkal Ilir kabupaten Tanjung jabung Barat.

Berdasarkan hasil olahan data diperoleh keterangan bahwa dilihat secara keseluruhan pernyataan yang diajukan ternyata dari 40 responden yang dinilai dengan 8 pernyataan, sekitar 171 jawaban atau sekitar 53,44\% direspon oleh masing-masing pengusaha dengan jawaban kurang setuju dan dan tidak setuju. Sedangkan yang respon setuju dan sangat setuju adalah 149 jawaban. Ini menunjnukkan bahwa secara keseluruhan jawaban responden terhadap semua aspek yang ditanyakan tentang kinerja usahanya dapat dikatakan biassa saja. Hal ini juga sejalan dengan hasil pengkategorian jawaban responden yang berada pada angka 137,83 yang berada pada kategori biasa saja.

Jika hasil pengolahan data seperti yang diperlihatkan pada table 5.5 di atas dilihat dari dimensi yang ada, terlihat bahwa secara rata-rata penilaian tertinggi terletak pada dimensi kuantiitatif dengan skor rata-rata adalah 137. Jika penilaian kinerja di atas dilihat dari indikator yang ada, justru indikator yang memperoleh penilaian tertinggi adalah Indikator pelanggan, yaitu cenderung bertambahnya pelanggan setiap tahun. dengan skor 157, diikuti oleh tingginya penilaian terhadap indikator efektivitas (KU8) yaitu yang berkaitan dengan kebiasaan untuk menggunakan berbagai fasilitas dengan tepat guna dan tepat sasaran.

\subsection{Deskripsi Motivasi Kerja}

Motivasi kerja dalam penelitian ini dkembangkan dalam 3 (tiga) dimensi utama yaitu Needs for achieveement, Needs for affiliation, dan Needs for power, . Mengingat pernyataan tentang motivasi kerja yang diajukan hanya dinilai oleh masing-masing responden, maka dari hasil jawaban yang dikumpulkan terhadap 40 orang responden pengusaha kerupuk udang di Kecamatan Tungkal Ilir kabupaten Tanjung Jabung diperoleh bahwa dilihat secara keseluruhan pernyataan yang diajukan pada masing-masing responden ternyata dari 40 responden yang dinilai dengan 9 indikator/pernyataan, sekitar 185 atau sekitar 51.4\% jawaban direspon dengan jawaban setuju dan sangat setuju. Sedangkan yang respon kurang setuju sampai dengan sangat tidak setuju berjumlah 175 atau sekitar $48.6 \%$ jawaban. Ini menunjnukkan bahwa secara keseluruhan jawaban responden terhadap semua aspek yang ditanyakan tentang motivasi kerja pengusaha kerupuk udang di wilayah kecamatan Tungkal Ilir Kabupaten Tanjung Jabung Barat dapat dikatakan tinggi karena hanya 51,4\% dari 360 jawaban direspon dengan setuju dan sangat setuju. Hal ini juga sejalan dengan hasil pengkategorian jawaban responden yang berada pada angka 140,2 yang berada pada kategori tinggi.

Jika hasil pengolahan data seperti yang diperlihatkan pada table 5.6 di atas dilihat dari dimensi yang ada, terlihat bahwa secara rata-rata penilaian tertinggi terletak pada dimensi Needs for power dengan skor rata-rata 146,33. Tingginya penilaian dari dimensi Needs for power ini diikuti oleh tingginya penilaian pada dimensi Needs for Achievement dengan skor rata-rata sebesar 142.67. Jika penilaian motivasi kerja di atas dilihat dari indikator yang ada, justru indikator yang memperoleh penilaian tertinggi adalah Indikator bebas dalam bertindak dan berfikirk dengan skor 151, diikuti oleh tingginya penilaian terhadap indikator bebas dalam bekerja kreatif dengan skor 149. 


\subsection{Deskripsi Kemampuan Kerja}

Seperrti yang telah disebutkan sebelumnya bahwa untuk mengukur kemampuan kerja pengusaha kerupuk udang di Kecamatan Tungkal Ilir Kabupatenn Tanjung jabung Barat,, maka dalam hal ini peneliti menggunakan 3 Dimensi yang meliputi Dimensi Pengetahuan, Dimensi Keterampilan dan dimensi pengalaman, dimana masing-masing dmensi tersebut diukur melalui 2 indikator dan 2 indikator / pernyataan.

Dari data hasil olahan tentang jumlah tanggapan dan kategori tanggapan mengenai kemampuan kerja responden seperti yang terlihat pada table 5.4 diperoleh keterangan bahwa secara keseluruhan pernyataan yang diajukan pada masing-masing atasan responden ternyata dari 40 kuesioner yang dinilai dengan 6 (enam) pernyataan, sekitar 150 jawaban atau sekitar $62.5 \%$ direspon dengan jawaban kurang setuju dan tidak setuju. Sedangkan yang respon setuju dan sangat setuju berjumlah 90 jawaban atau sekitar 37.5\%. Ini menunjnukkan bahwa secara keseluruhan jawaban terhadap semua aspek yang ditanyakan tentang kemampuan kerja, baik dari aspek pengetahuan, keterampilan dan pengalaman para pengusaha kerupuk uudang di wilatyah Kecamatan Tungkal IlirJKabupaten Tanjung Jabung Baarat dapat dikatakan sedang atau biasabiasa saja. Hal ini juga sejalan dengan hasil pengkategorian jawaban responden yang berada pada kategori 131.5 yang berada pada kategori biasa-biasa saja.

Jika hasil pengolahan data seperti yang diperlihatkan pada table 5.7 di atas dilihat dari dimensi yang ada, terlihat bahwa secara rata-rata penilaian tertinggi terletak pada dimensi pengetahuan dengan skor rata-rata adalah 139. Tingginya penilaian dari dimensi pengetahuan ini diikuti oleh tingginya penilaian pada dimensi pengalaman dengan skor rata-rata sebesar128.5dan dimensi keterampilan dengan skor rata-rata adalah 127.. Jika penilaian kemampuan kerja di atas dilihat dari indikator yang ada, justru indikator yang memperoleh penilaian tertinggi adalah Indikator kemampuan dalam menyelesaikan tugas (KMP1) dan Kemampuan untuk membuat gagasan kreatif (KMP2).

\subsection{Deskripsi Tentang Kreativitas}

Dalam penelitian ini, variabel kreativitas dikembangkan kedalam beberapa dimensi, diantaranya adalah (a) Baru (b) berguna dan (c) dapat dimengertiUntuk masing-masing dimensi tersebut dikembangkan lagi dalam bentuk 6 indikator / pernyataan.

Dari data hasil olahan tentang jumlah tanggapan dan kategori tanggapan mengenai kreativitas responden seperti yang terlihat pada table 5.5 diperoleh keterangan bahwa secara keseluruhan pernyataan yang diajukan pada masing-masing atasan responden ternyata dari 40 kuesioner yang dinilai dengan 6 (enam) pernyataan, sekitar 125 jawaban atau sekitar $52.08 \%$ direspon dengan jawaban kurang setuju dan tidak setuju. Sedangkan yang respon setuju dan sangat setuju berjumlah 115 jawaban atau sekitar 47.925\%. Ini menunjnukkan bahwa secara keseluruhan jawaban terhadap semua aspek yang ditanyakan tentang kreativitas, dapat dikatakan sedang atau biasa-biasa saja. Hal ini juga sejalan dengan hasil pengkategorian jawaban responden yang berada pada kategori 138.5 yang berada pada kategori biasa-biasa saja.

Jika hasil pengolahan data seperti yang diperlihatkan pada table 5.8 di atas dilihat dari dimensi yang ada, terlihat bahwa secara rata-rata penilaian tertinggi terletak pada dimensi berguna dengan skor rata-rata adalah 151 . Tingginya penilaian dari dimensi berguna ini diikuti oleh tingginya penilaian pada dimensi dapat dimengerti dengan skor rata-rata sebesar $132.5 \mathrm{dan}$ dimensi baru dengan skor rata-rata adalah 132.. Jika penilaian kreativitas di atas dilihat dari indikator yang ada, justru indikator yang memperoleh penilaian tertinggi adalah Indikator cita rasa produk (KRE4) dan kemasan produk (KRE3). 


\subsection{Perhitungan Korelasi}

Tehnik korelasi ini digunakan untuk mengukur kekuatan hubungan linier antara dua variabel yang diteliti. Kuatnya hubungan antara variabel dinyatakan dalam koeifisien korelasi. Koeifisien korelasi positif terbesar adalah 1 dan koeifisien negative terbesar adalah -1, sedangkan yang terkecil adalah 0. Bila hubungan antar dua variabel atau lebih itu mempunyai koeifisien korelasi adalah 1 atau - 1, maka hubungan tersebut adalah sempurna. Dalam artian bahwa kejadian-kejadian pada variabel yang satu akan dapat dijelaskan atau diprediksikan oleh variabel lain tanpa terjadi kesalahan (error). Dari pengolahan data melalui perangkat komputer jenis SPSS 17 diperoleh hasil analisis korelasinya sebagai berikut :

Tabel 2. Korelasi antara Kinerja Usaha, Motivasi kerja, kemampuan, Kreativitas

\begin{tabular}{clcccc}
\hline & $\begin{array}{c}\text { Kinerja } \\
\text { Usaha }\end{array}$ & $\begin{array}{c}\text { Motivasi } \\
\text { kerja }\end{array}$ & $\begin{array}{c}\text { Kemampuan } \\
\text { kerja }\end{array}$ & Kreativitas \\
\hline & $\begin{array}{l}\text { Kinerja } \\
\text { Usaha }\end{array}$ & 1.000 & 0.845 & 0.676 & 0.864 \\
$\begin{array}{l}\text { Motivasi } \\
\text { Pearson }\end{array}$ & 0.845 & 1.000 & 0.556 & 0.787 \\
kerja & $\begin{array}{l}\text { Kemampuan } \\
\text { kerja }\end{array}$ & 0.676 & 0.556 & 1.000 & 0.615 \\
& $\begin{array}{l}\text { Kreativitas } \\
\text { Krelation }\end{array}$ & 0.864 & 0.787 & 0.615 & 1.000 \\
\hline
\end{tabular}

Tabel 2 di atas menunjukkan bahwa besar hubungan antara variabel motivasi kerja dengan Kinerja usaha yang dihitung dengan koeifisien korelasi adalah 0,845 dengan angka signifikansi adalah sebesar 0,000. Angka 0,845 tersebut adalah positif dan dapat dikatakan kuat dan uji signifikansi 0,000 yang berarti hubungan keduanya signifikan. Selanjutnya, Korelasi antara variabel kemampua kerja dengan kinerja usaha adalah 0,676 dengan angka signifikansi 0.000 yang menunjukkan bahwa hubungan keduanya kuat dan cukup signifikan. Demikian juga hubungan antara variabel kreativitas ja dengan kinerja usaha adalah sebesar 0,864 dengan angka signifikansi 0,000 yang nmenunjukkan hubbungan kuat dan positif serta signifikan. Dari ketiga hubungan antara variabel - variabel independent dengan variabel dependen (kinerja usaha pengusaha kerupuk udan di wilayah kecamatan tungkal ilir Kabupaten Tanjung Jabung Barat), ternyata kreativitas memiliki hubungan yang paling dominan dibandingkan dengan variabel lainnya.

\subsection{Perhitungan Regresi}

Cara ini dimaksudkan untuk menjelaskan besaran pengaruh dari variabel - variabel independent terhadap variabel dependen, dalm hal ini pengaruh dari variabel - variabel motivasin kerja, kemampuan kerja dan kreativitas terhadap kinerja usaha pengusaha kerupuk udan di wilayah kecamatan tungkal ilir Kabupaten Tanjung Jabung Barat. Jenis regresi yang digunakan untuk analisis ini adalah jenis regresi Linier berganda, dimana kinerja pegawai tersebut merupakan fungsi dari ketiga variabel independen dimaksud. Dari hasil pengolahan data melalui perangkat komputer jenis SPSS seperti yang terlihat pada Lampiran 11 pada bagian coefficient diperoleh persamaan regresi Linier bergandanya sebagai berikut :

$$
\mathrm{Y}=-0,236+0,444 \mathrm{X}_{1}+0.296 \mathrm{X}_{2}+0,449 \mathrm{X}_{3}+\mathrm{e}
$$


Nilai konstanta sebesar -0,236 menyatakan bahwa jika variabel independent yang dalam hal ini adalah motivasi kerja, kemampuan kerja dan kreativitas, dianggap tidak ada (nol), maka rata-rata kinerja usaha pengusaha kerupuk udan di wilayah kecamatan tungkal ilir Kabupaten Tanjung Jabung Barat adalah sebesar -0,236. Koeifisien regresi $\mathrm{X}_{1}$ (motivasi kerja) sebesar 0.444 menyatakan bahwa setiap kenaikan skor motivasi kerja sebesar satu satuan akan meningkatkan skor kinerja usaha sebesar 0,444 satuan. Koeifisien regresi $X_{2}$ (kemampuan kerja) sebesar 0,296 menyatakan bahwa setiap kenaikan skor variabel usaha sebesar 0,296 satuan. Demikian juga dengan koeifisien regresi X3 (kreativitas) sebesar 0,449 $\mathrm{X}_{3}$ menyatakan bahwa setiap kenaikan skor variabel kreativitassebesar satu satuan akan meningkatkan kinerja usaha sebesar 0,449 satuan.

\section{KESIMPULAN DAN SARAN}

Sesuai dengan tujuan yang akan dicapai dalam penelitian ini yaitu : ingin memperoleh gambaran tentang kinerja usaha, motvasi kerja, kemampuan kerja dan kreativitas pengusaha kerupuk udang di Wilayah Kecamatan Tungkal Ilir kabupaten Tanjung jabung Barat serta Ingin mengetahui pengaruh motivasi kerja, kemampuan kerja dan kreativitas tersebut terhadap kinerja usaha pengusaha kerupuk udang di Wilayah Kecamatan Tungkal Ilir kabupaten Tanjung jabung Barat, baik secara parsial maupun secara simultan. Berdasarkan Uraian hasil penelitian dan pembahasan penelitian sebagaimana yang diuraikan pada Bab sebelumnya, maka dapat ditarik beberapa kesimpulan sebagai berikut:

1) Dalam kaitannya dengan kinerja diperoleh bahwa kinerja usaha pengusaha kerupuk udang di Wilayah Kecamatan Tungkal Ilir kabupaten Tanjung jabung Barat yang diukur dari dimensi ukuran kuantitas dan ukuran kualitas dikategorikan sedang. Dari beberapa dimensi tersebut, ternyata indikator perluasan daerah pemasaran mempunyai skor penilaian relatif lebih rendah dari yang lainnya.

2) Untuk motivasi kerja diperoleh bahwa motivasi kerja pengusaha kerupuk udang di Wilayah Kecamatan Tungkal Ilir kabupaten Tanjung jabung Barat yang diukur dari 3 dimensi Needs for achievement, needs for affiliation dan needs for power, dikategorikan tinggi. Dari beberapa dimensi tersebut ternyata dimensi needs for power memiliki skor relatif lebih tinggi dari dimensi yang lainnya.Sementara itu dari indikator needs for affiliation ternyata penilaiannya relatif lebih rendah dari yang lainnya terutama yang berhubungan dengan kesediaan untuk menerima segala kenyataan yang ada.

3) Untuk kemampuan kerja diperoleh bahwa kemampuan kerja pengusaha kerupuk udang di Wilayah Kecamatan Tungkal Ilir kabupaten Tanjung jabung Barat yang diukur dari 3 dimensi pengetahuan, keterampilan dan pengalaman dikategorikan sedang. Dari beberapa dimensi tersebut ternyata dimensi pengetahuan relatif lebih tinggi dari yang lainnya. Sementara yang memiliki nilai relatif lebih rendah dari yang lainnya adalah yang berkaitan dengan kemampuan pengushaa untuk mencari cara lain dalam mengerjakan tugas.

4) Untuk kreativitas, diperoleh bahwa kreativitas pengusaha kerupuk udang di Wilayah Kecamatan Tungkal Ilir kabupaten Tanjung jabung Barat yang diukur dari dimensi menemukan hal-hal baru, mewnemukan hal-hal yang bergfuna serta menemukan sesuatu yang dapat dimengerti dikategorikan sedang. Dari beberapa dimensi tersebut, ternyata dimensi yang berkaitan dengan upaya untuk mencitakan sesuatu yang berguna dari produk yang mereka hasilkan mempunyai skor penilaian relatif lebih tinggi dari yang lainnya terutama yang berkaitan dengan cita rasa produk. Namun dalam hal menciptakan cara proses produksi yang mudah dimengerti orang lainnya masih dinilai realatif lebih rendah dari yang lainnya. 
5) Secara simultan motivasui kerja, kemampuan kerja dan kreativitas pengusaha berpengaruh positif terhadap kinerja usaha pengusaha kerupuk udang di Wilayah Kecamatan Tungkal Ilir kabupaten Tanjung jabung Barat. Ini memberikan makna bahwa tingginya motivasi kerja, kemampuan kerja, dan kreativitas pengusaha secara bersamasama memberikan kontribusi positif terhadap tingginya kinerja usaha pengusaha kerupuk udang di Wilayah Kecamatan Tungkal Ilir kabupaten Tanjung jabung Barat.

6) Secara parsial motivasi kerja pegawai berpengaruh positif terhadap kinerja usaha. Hal ini memberikan makna bahwa belum optimalnya kinerja pengusaha kerupuk udang di Wilayah Kecamatan Tungkal Ilir kabupaten Tanjung jabung Barat ditentukan oleh belum maksimalnya motivasi kerja yang dimiliki oleh pengusaha.

7) Secara parsial Kemampuan kerja pegawai berpengaruh positif terhadap kinerja usaha. Hal ini memberikan makna bahwa belum optimalnya kinerja usaha pengusaha kerupuk udang di Wilayah Kecamatan Tungkal Ilir kabupaten Tanjung jabung Barat ditentukan oleh kemampuan kerja pengusaha yang belum sesuai dengan harapan.

8) Secara parsial kreativitas berpengaruh positif dan signifikan terhadap Kinerja usaha..Hal ini memberikan makna bahwa belum optimalnya kinerja usaha pengusaha kerupuk udang di Wilayah Kecamatan Tungkal Ilir kabupaten Tanjung jabung Barat ditentukan oleh masih belum maksimalnya kreativitas dari pengusaha itu sendiri..

\section{Saran}

1) Berkaitan dengan kinerja pngusaha kerupuk udang di wilayah kecmatan tungkal ilir Kabuppaten tanjung jabung Barat perlu memikirkan perluasan daerah pemasarannya ke tempat-tempat lain, baik dalam lingkup wilayah Kabuaten tanjung jabung Barat maupun di wilayah luar kabupaten Tanjung jabung Barat. Hal yang perlu dilakukan adalah mencari informasi dari berbagai fihak tentang kemungkinan per;uasan daerah pemasaran tersebut.

2) Dalam kaitannya dengan motivasi kerja pengusaha, maka hal yang perlu ditingjkatkab adalah bagaimana agar pengusaha kerupuk udang yanjg ada di wilayah Kecamatan tungkal Ilir ini bisa menerima kenyataan yang ada, tentang keberhasilan dan kegagalam yang diterimanya sdelama melakukan aktivitas usahanya.

3) Berkaitan dengan kemampuan kerja pegawai pegawai, mengingat selama ini aspek yang paling terendah adalah berkaitan dengan kemampuan pengushaa untuk mencari cara lain dalam menghasilka produk., maka kedepannya nanti persoalan ini perlu dibenahi. Cara yang mungkin dapat dilakukan adalah dengan perlunya upaya terus belajar mencari cara lain untuk mampu memodifikasi cara pengerjaann produk agar memiliki cita vrasa yang diinginkan oleh konsumen.

4) Dalam kaitannya dengan kreativitas kerja, maka yang perlu dilakukan oleh pengusaha adalah bagaimana mereka dapat menciptakan kerupuk udang yang dalam pelaksanaan proses produksinya mudah dimengerti dan difahami oleh para pekerjanya.

\section{UCAPAN TERIMA KASIH}

Puji Syukur Penulis haturkan kehadirat Allah SWT, karena berkat rahmat dan hidayahnya jualah, penelitian ini dapat diselesaikan dengan tanpa adanya rintangan yang berarti. Penulis melakukan penelitian ini karena terdorong oleh adanya rasa keingin tahuan penulis untuk melihat apakah terdapat pengaruh motivasi kerja, kemampuan dan kreativitas terhadap kinerja usaha pengusaha kerupuk udang di Kecamatan Tungkal Ilir. Untuk memperlancar jalannya proses penelitian ini, tentunya penulis banyak dibantu oleh berbagai fihak, baik bantuan dalam bentuk dana maupun dalam bentuk tenaga. Karena tanpa bantuan fihak-fihak tersebut, mustahil penelitian ini dapat 
terselenggara. Oleh karena itulah, maka dalam kesempatan ini penulis mengucapkan menyak terima kasih terutama kepada Rektor Universitas Jambi, Dekan Fakultas Ekonomi Dan Bisnis Universitas Jambi, Ketua Jurusan Manajemen Fakultas Ekonomi Dan Bisnis Universitas jambi , Ketua lembaga Penelitian Universitas Jambi serta fihak-fihak lain yang sulit rasanya disebutkan satu per satu dalam kesempatan ini. Atas bantuan tersebut, saya sebagai penulis mengucapkan banyak terima kasih.

\section{DAFTAR PUSTAKA}

Amir Thoha, 2014. Pengaruh motivasi belajar dan kreativitas terhadap prestasi belajar siswa MTS Miftahul Ulum Matesih Karanganyar. UNDIP.

Cassel, C., Nadin, S., Gray, M., and Clegg, C, 2002, Exploring Human Resource Management Practices in Small and Medium Sized Entreprises. Personnel Review, 31: 671-692

Craft Ana. 2005. Membangun Kreativitas Anak. Depok: Insani Press

Christian Tri Widodo, 2015. Pengaruh kreativitas dan inovasi terhadap kinerja usaha (survey pada sentra UKM Industri kaos sablon suci bandung). UNPAD. Jurnal.

Ghozali, Imam, 2013. Aplikasi Analisis Multivariate dengan Program SPSS. Yogyakarta: Badan Penerbit BPFE.

Gujarati, Damodar, 2003, Ekonometri Dasar. Terjemahan: Sumarno Zain, Jakarta: Erlangga.

Hurlock, E. B., 1993. Psikologi Perkembangan (Suatu Pendekatan Sepanjang Rentang Kehidupan), edisi kelima. Penerbit Erlangga : Jakarta.

Husein Oemar, 2008. Riset sumberdaya manusia Dalam Organisasi. Gramedia Pustaka Utama. Jakarta.

Indarjanti dan Bodroastuti, 2012. Tesis "Pengaruh Kemampuan, Usaha Dan Dukungan Organisasi terhadap kinerja BAAK staf Universitas Diponegoro, UNDIP

Kuncoro, Mudrajad (2006), Strategi: Bagaimana Meraih Keunggulan Kompetitif. Jakarta: Erlangga

Mangkunegara, Anwar Prabu. 2005. Manajemen Sumber Daya Manusia Perusahaan. Cetakan Keenam. Bandung: PT. Remaja Rosdakarya.

Manguhardjana, 2006. Mengemukakan Kreativitas, Salemba Empat, Jakarta

Manullang, M. 2004. Manajemen Sumber Daya Manusia,. BPFE, Yogyakarta

McNeese-Smith, Donna, 1996, "Increasing Employee Productivity, Job Satisfaction, and Organizational Commitment" Hospital \& Health Services Administration, Vol. 41: 2, p. 160-175

Moenir, A.S, 2003, Pendekatan Manusiawi Dalam Organisasi Terhadap Pembinaan Kepegawaian, Gunung Agung Jakarta

Munandar, Ashar Sunyoto, 2009, Psikologi Indutri dan Organisasi, Universitas Indonesia, Jakarta.

Ndraha, Talizuduhu, 2007. Teori Budaya Organisasi. Penerbit Rineka Cipta Jakarta.

Nurianna Thoha (2008), Kompetensi Plus : Teori, Desain, Kasus dan Penerapan Untuk HR dan Organisasi yang dinamis.. PT Gramedia Pustaka Utama 
Ridwan, 2002. Skala Pengukuran variabel-variabel Penelitian. Cetakan ketiga. Bandung. PT Alfabetta

Retno Kurnia Nurzaman, 2014. Pengaruh Kemampuan wirausaha dan kreativitas terhadap keberhasilan usaha pada restoran sindang reret cabang surapati Bandung. Uniersitas Komputer Indonesia.

Robert L. Mathis \& John H. Jackson, 2001, Manajemen Sumber Daya Manusia, Penerbit

Salemba Empat, Jakarta.

Robbins, Stephen P., 1998, Perilaku Organisasi, Edisi Bahasa Indonesia Cetakan Ke dua, Prenhallindo, Jakarta.

Robbins, Stephen P. Timothy A. Judge. 2009. Perilaku Organisasi, Edisi 12. Jakarta : Salemba Empat

Rogers, Everett M, 1995, Diffusions of Innovations, Forth Edition. New York: Tree Press.

Simamora, Henry, 2002, Manajemen Sumber Daya Manusia, STIE YKPN, Yogyakarta

Schuler, Randall S, 2004. Managing Human Resources. $5^{\text {th }}$ Edition. Minnepolis / St. Paul : West Publishing Company

Soedarmayanti, 2003. Tata Kerja Dan Produktivitas kerja. PT Mandar Maju, Jakarta

Siagian, Sondang P. 2004. Teori Motivasi dan Aplikasinya, Cetakan ketiga. Jakarta : PT. Rineka Cipta

Sugiyono, 2006. “Metode Penelitian Bisnis”.Cetakan keenam. Alfabeta: Bandung

Suja'I, Inovasi Pembelajaran Bahasa Arab, (Semarang: Walisongo Press, 2008), 14-15.

Suryana. 2008. Kewirausahaan, Pedoman Praktis, Kiat dan Proses Menunju Sukses, Edisi Revisi, Jakarta: Salemba Empat.

Suyadi Prawirosentono. (2008). Manajemen Sumber Daya ManusiaKebijakan Kinerja Karyawan”. Yogyakarta:BPFE. 